\title{
Facilities of J. G. Mendel Antarctic station: Technical and technological solutions with a special respect to energy sources
}

\author{
Pavel Prošek ${ }^{1 *}$, Miloš Barták $^{2}$, Kamil Láska ${ }^{1}$, Alois Suchánek ${ }^{3}$, Josef \\ Hájek $^{2}$, Pavel Kapler ${ }^{1}$ \\ ${ }^{1}$ Department of Geography, Faculty of Science, Masaryk University, Kotlářská 2, 61137 \\ Brno, Czech Republic \\ ${ }^{2}$ Department of Experimental Biology, Faculty of Science, Masaryk University, Campus \\ Bohunice, Kamenice 5, 62500 Brno, Czech Republic \\ ${ }^{3}$ PSG, Otrokovice, Napajedelská 1552, 76502 Otrokovice, Czech Republic
}

\begin{abstract}
In this paper, we focus on technical facilities and technologies used at the Johann Gregor Mendel station (James Ross Island, Antarctica) with a special respect to energy sources used for running the station. Construction of the station is evaluated from energy demand and energy loss points of view. Detailed description of main energy sources, i.e. wind turbines, solar thermal panels, and diesel generators is given. Water management and combustible solid waste management are described as well. Brief overview of future plans related to energy sources at the Johann Gregor Mendel station including an increase in the exploitation of solar energy from photovoltaic panels is given.
\end{abstract}

Key words: Renewable energy, wind turbine, solar thermal panel, photovoltaic panel, waste, building construction

DOI: $10.5817 / C P R 2013-1-7$

\section{Introduction}

Both permanent and austral summer season-operated Antarctic stations established before 1990 have used dieselelectric generators as main energy source supplying the stations with electric power. At the beginning of the 90 -ies, however, many specialists suggested to increase the proportion of alternative energy sources to be exploited at Antarctic stations (e.g. Guichard et Steel 1993, Steel 1993). Since that, several alternative sources of energy and combined energetical systems have been tested at Antarctic stations including e.g. fuel cells (see Datta et al. 2002, Maitri station). Recently, however, there is a strong trend to use renewable energy sources in Antarctic stations. Traditional stations, that in majority of cases use diesel generators as main energy source, are producers and emitters of exhaust gases, such as e.g. $\mathrm{CO}_{2}, \mathrm{CH}_{4}, \mathrm{NO}_{\mathrm{x}}$ and hydrocarbons. To minimize the emissions,

Received January 2, 2013, accepted March 28, 2013.

${ }^{*}$ Corresponding author: Pavel Prošek < prosek@sci.muni.cz>

Acknowledgements: The infrastructure of J. G. Mendel Czech Antarctic station is supported by the Ministry of Education, Youth and Sports of the Czech Republic within the framework of the Project of Large Research, Experimental Development and Innovation Infrastructure; hereby the project CzechPolar - Czech Polar stations: Construction and Operational Costs (LM2010009).The authors are indebted to the CzechPolar project used for support and development of infrastructure of Czech Antarctic station J. G. Mendel (James Ross Island, Antarctica). 
many national Antarctic programmes started to make an inventory of exhaust gases sources at particular station (see e.g. Leripio et al. 2012) and suggest alternative sources of energy with the main emphasis given to wind power energy. In new Antarctic station that have been built and started to operate within last decade, exploitation of alternative source energy becomes a standard. Such trend is clearly demonstrated at newly opened Princess Elisabeth station which is designed as to be run fully on renewable energy. Substantial part (about 65\%) of energy is provided by wind turbines and the rest of energy demands are covered by photovoltaic solar panels and thermal solar panels (anonymous 2007). Over last decade, many national Antarctic programmes have evaluated renewable energy sources and increase their proportion in total energy budget of particular Antarctic stations (see e.g. Chinese Dome A station anonymous 2008, Indian Maitri station - Ramesh 2000). This trend can be demonstrated on the example of South African station SANAE IV that have increased amount of energy from wind (Teetz et al. 2003) and solar radiation (Olivier et al. 2008) within last decade. Recently, optimization of energy budget and involve-

\section{Material and Methods}

\section{Site selection}

As a result of two survey ship expedition and reconnaissance on the northern coast of Antarctic Peninsula that were carried out in February and March of 2002 and 2004, the northern coast of James Ross Island was selected as optimal location for the construction of a Czech station. Satellite and detailed aerial photographs of James Ross Island northern coast were analyzed so that suitable sites for station construction could be selected. Different environmental factors of the sites ment of modern technologies used in the constructions of Antarctic stations become a challenge for design of stations potentially built on other planets (Broughton 2010).

Because of favorable environmental conditions (i.e. strong winds all yearround), wind energy could be used in Antarctica as important energy source for Antarctic stations in operation. However, variety technical problems still need to be solved because extreme Antarctic conditions (cold, strong and gusty winds and snow accumulation) bring technical failures more frequently than under optimum conditions. In spite of that, wind energy is increasingly been used in Antarctica mainly in austral summer season when energy demands increase due to large number of expedition members visiting particular stations (Tin et al. 2009). Johann Gregor Mendel station (denoted as J. G. Mendel station in the following text) was built within the period of 2005-2006. Therefore, it can be ranked among young ones. Contrastingly to older station built before the 70-ies, its energy efficiency is high because of the use of alternative energy sources. In this paper, we bring an overview of technical solutions used in the J. G. Mendel station. proposed for the station were assessed during the workshop with the experts operating in the area. The evaluation included climatic, geological, geomorphological and biological conditions, quality of water sources, orientation of locations with respect to solar and wind energy utilisation, sea coast bathymetry, accessibility for disembarkation, and construction. Altogether, eight locations on the coast of the northern part of the island were selected (most of them had not 
geographical names and were, therefore, marked as sites indicated by numbers 1-8). Majority of them were located in the Brandy Bay and the northern coast between Bibby Point, Cape Lachman and Solorina Valley (see Fig. 1). Apart of biological and ecological criteria, final selection of a single site was made according to the following major priorities
(1) accessibility by a ship and/or helicopter flights from neigbouring stations (Marambio, Esperanza), (2) suitable landing site for logistic operations using rubber boats, floating platforms, (3) ability to conduct scientific activities in a wide variety of Antarctic ecosystem in walking distance from the station.

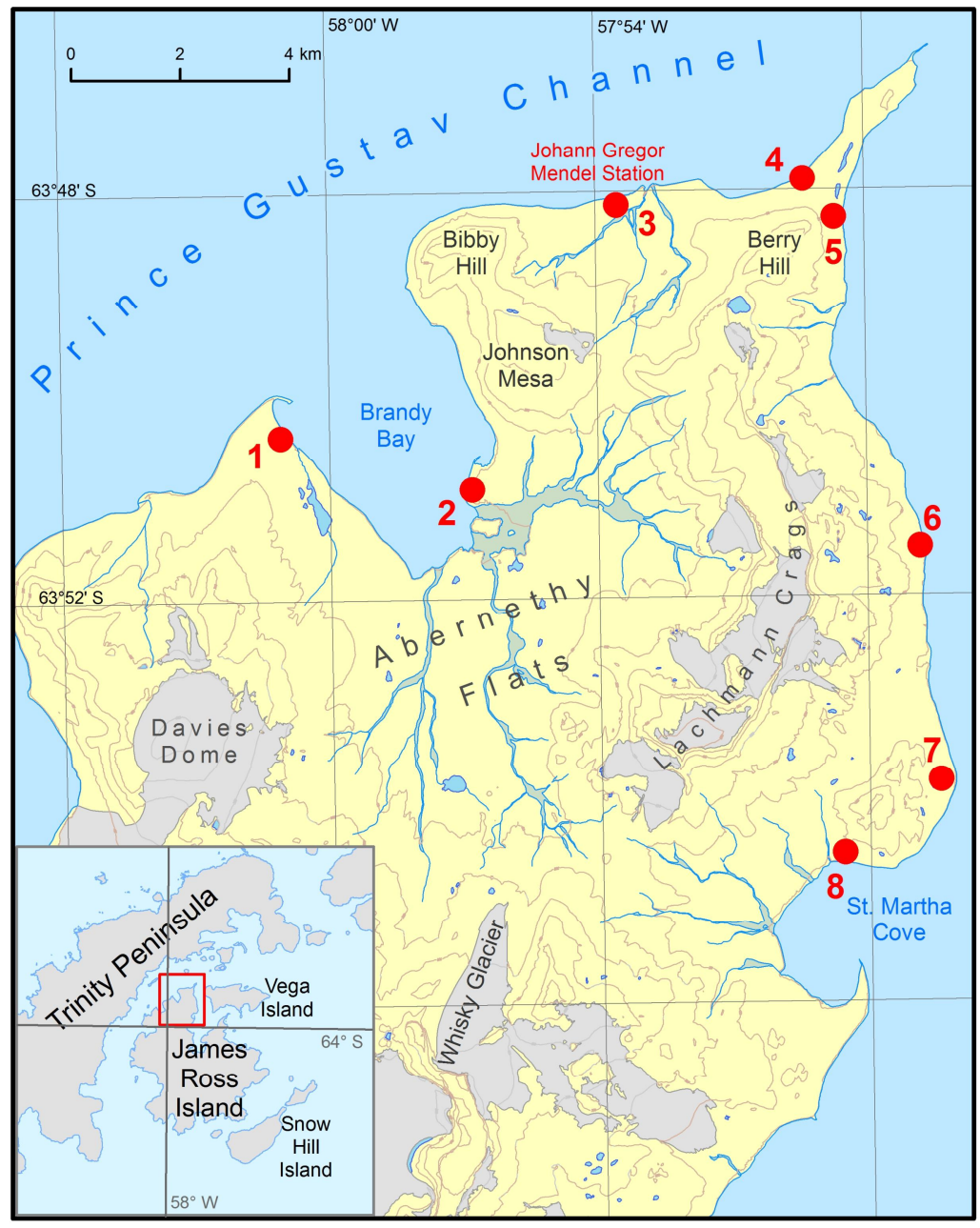

Fig. 1. Location of possible construction sites of the J.G.Mendel station at the northern part of James Ross Island as considered for planning in 2003. Numbers indicate individual sites: 1 Phormidium Lake, 2 - Brandy Bay, 3 - northerh coast of the James Ross Island (J. G. Mendel station site), 4 - northern coast close to the Berry Hill mesa, 5 - Small Lachman Lake, 6 Solorina Valley I, 7 - Solorina Valley II, St. Martha Cove. Visualization based on the data provided by the Czech Geological Survey, 2009. 


\section{Transport of construction components, and disembarkation}

All construction parts and technical systems of the building were completed and tested before transportation in the selected industrial companies in the Czech Republic, mainly in PSG International, P.L.C. Zlín (Czech Republic). The whole equipment weighing about 250 tones was transported by the assistance of Czechoslovak Ocean Shipping, Ltd. (Prague, Czech Republic) from Hamburg to Punta Arenas (Chile). After reloading to Chilean Navy icebreaker Almirante Viel, the

\section{Construction site}

The building site is located $100 \mathrm{~m}$ from a sea shore at the altitude of $9 \mathrm{~m}$ a.s.l. on a marine terrace formed by compacted and fine-grained sandy substrate (see Fig. 2). James Ross Island is situated in precipitation shadow of Antarctic Peninsula. Precipitation deficit in this area do not cause the soaking of the regolith around building foundations. However, occasional equipment was carried to the James Ross Island in two consecutive austral summer seasons of 2005 and 2006. Thanks to optimal weather and sea-ice conditions on the Prince Gustav Channel, the disembarkation lasted 3 days only. A half of the station building was built in the period from February to March 2005. In the next year (spring 2006), the second half of main building was finished and the technical systems put in operation.

snow accumulations after snow storms may provide certain amount of water after rapid thawing in summer months (Láska et al. 2011a). However, they are fully absorbed by well-sorted sandy sediments. Therefore, thawing water does not represent direct risk to the foundations of the main building (anonymous 2004).

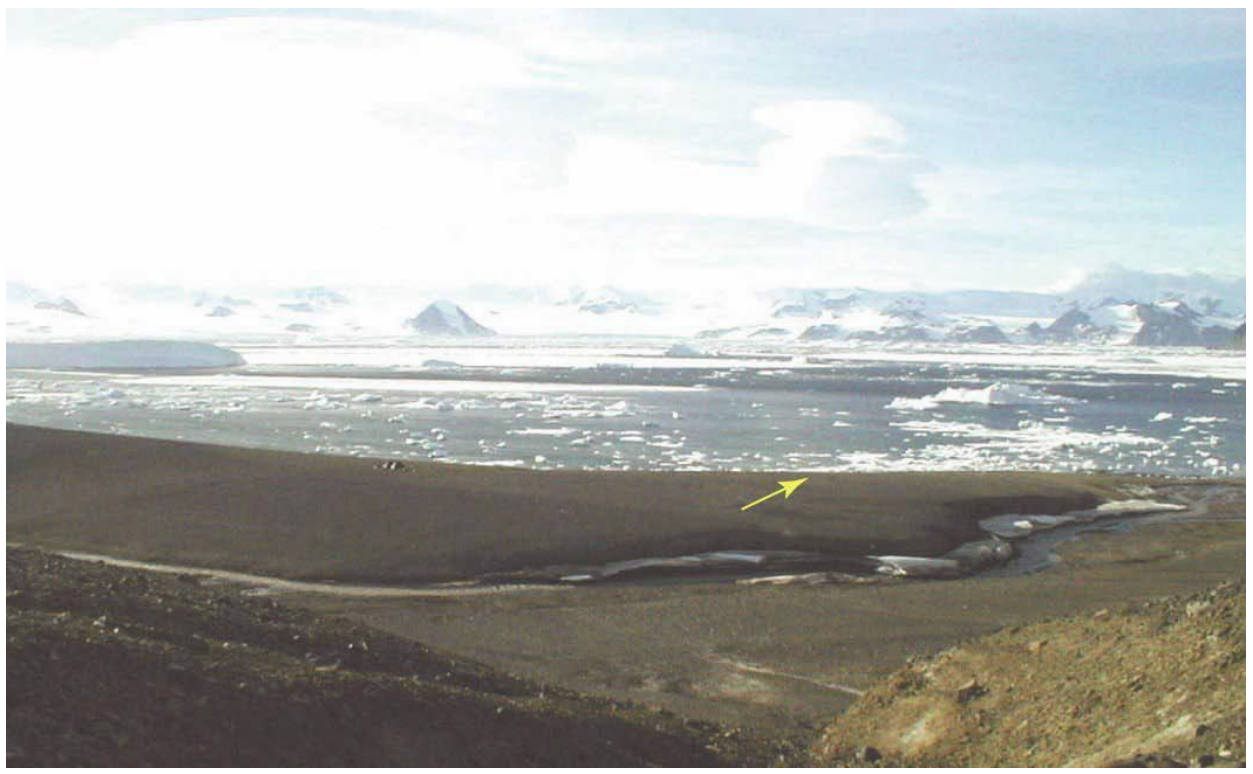

Fig. 2. A seashore terrace with the indication (an arrow) of station site in 2003. The stream below the terrace is the main water source for the station. (C) Photo: D. Nývlt. 


\section{Results and Discussion}

\section{Construction of main building}

The station consists of the main building, ancillary buildings (cargo containers - see Fig. 9) and engineering structures. The main building of the station layout is $26.5 \times 11.5$ meters. The height of the building is 2.8 to 3.6 meters (see Fig. $5)$. The main building is used for accommodation, catering and has several rooms that serve for hygienic and personal needs and scientific work of the expedition members. Moreover, it contains water supply unit and a kitchen, warehouse equipment for field activities, dressing room and a drying room. Therefore, the building is divided into several sections providing accommodation, social area, technical facilities and two laboratories for scientific work. Construction of the J. G. Mendel station was described in details by Prošek et al. (2006). Therefore, only brief overview is reported in this paper.

The building is based on a grate made of railway oak sleepers fixed in the ground. They were deposited in shallow grooves and connected. The grate system (see Fig. 3) forms a $40 \mathrm{~cm}$ high (minimum value) support construction on which the main building is placed. Supporting platform contains large air gaps which minimize contact of the building floor with ground and thus prevents thermal energy losses from the building. The main building is a one-story structure, walls of which are built from the K-Kontrol construction system. The system comprises sandwich panels consisting of two OSB (oriented strand board) chipboards with an inner insulation layer of selfextinguishing polystyrene foam. Floor and roof panels are $320 \mathrm{~mm}$ thick, while those forming external walls are thinner (265 $\mathrm{mm})$.

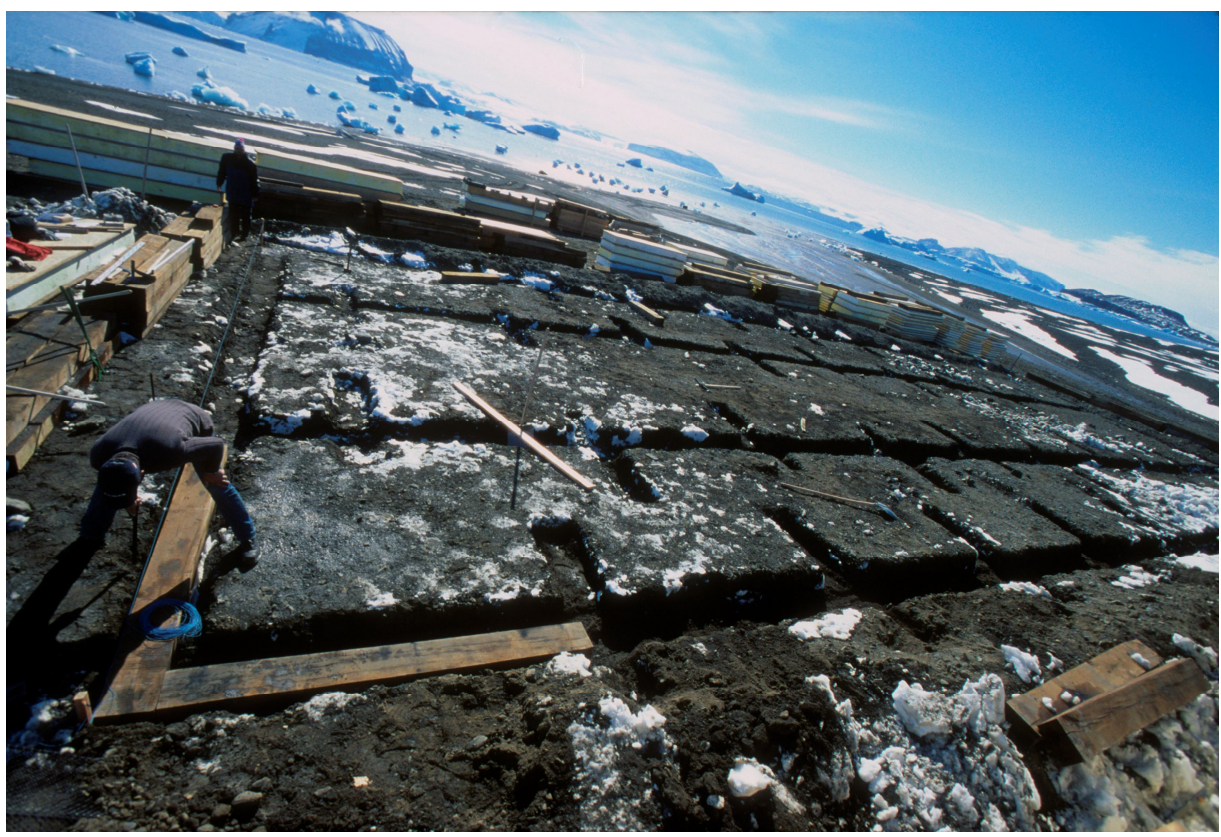

Fig. 3. Foundations of main building create the graps made from oak railway sleepers. (C) Photo: H. Adámek. 

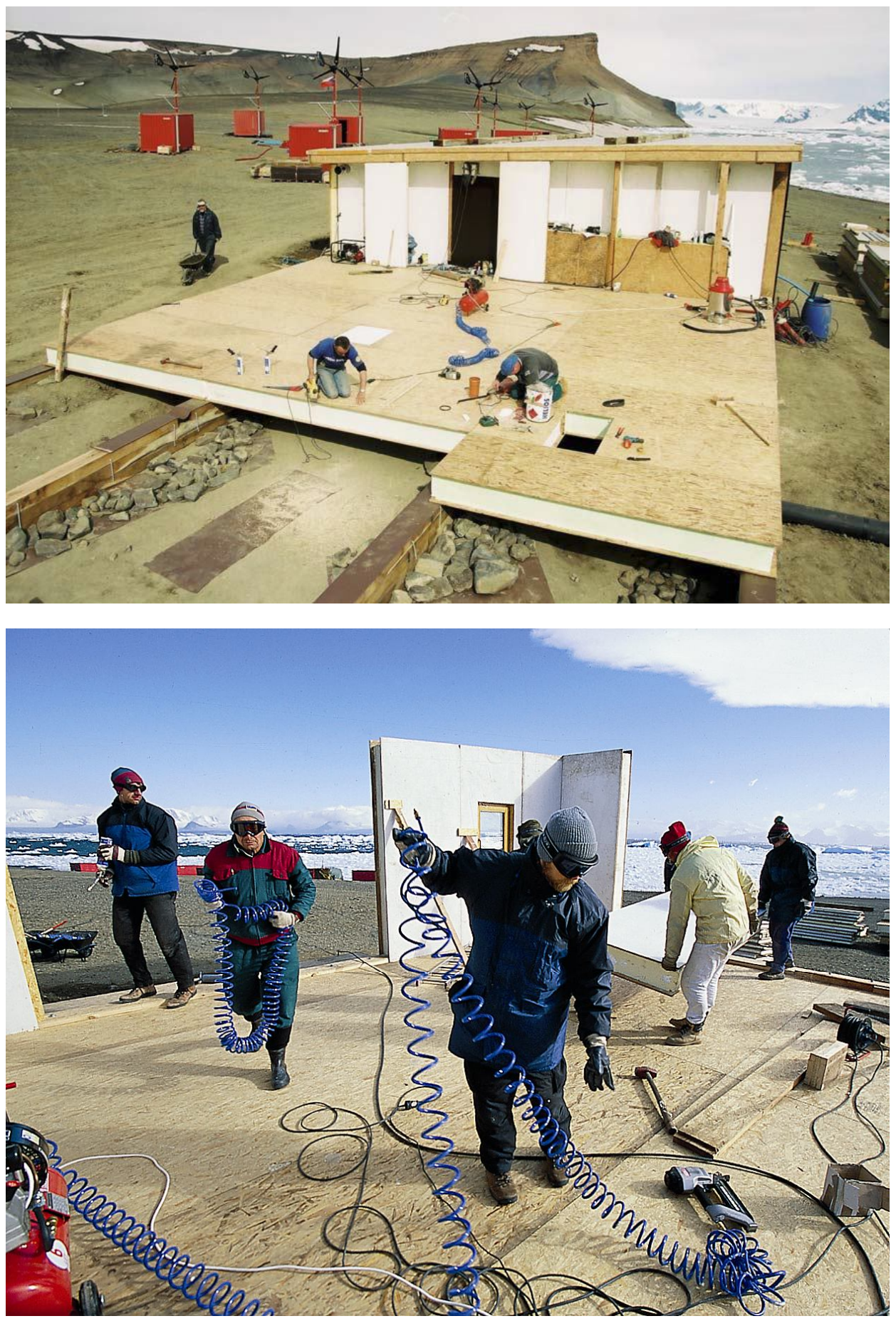

Fig. 4. K-Kontrol construction system is based on sandwich panels made of two OSB chipboards and inner insulation layer. (C) Photo: H. Adámek. 

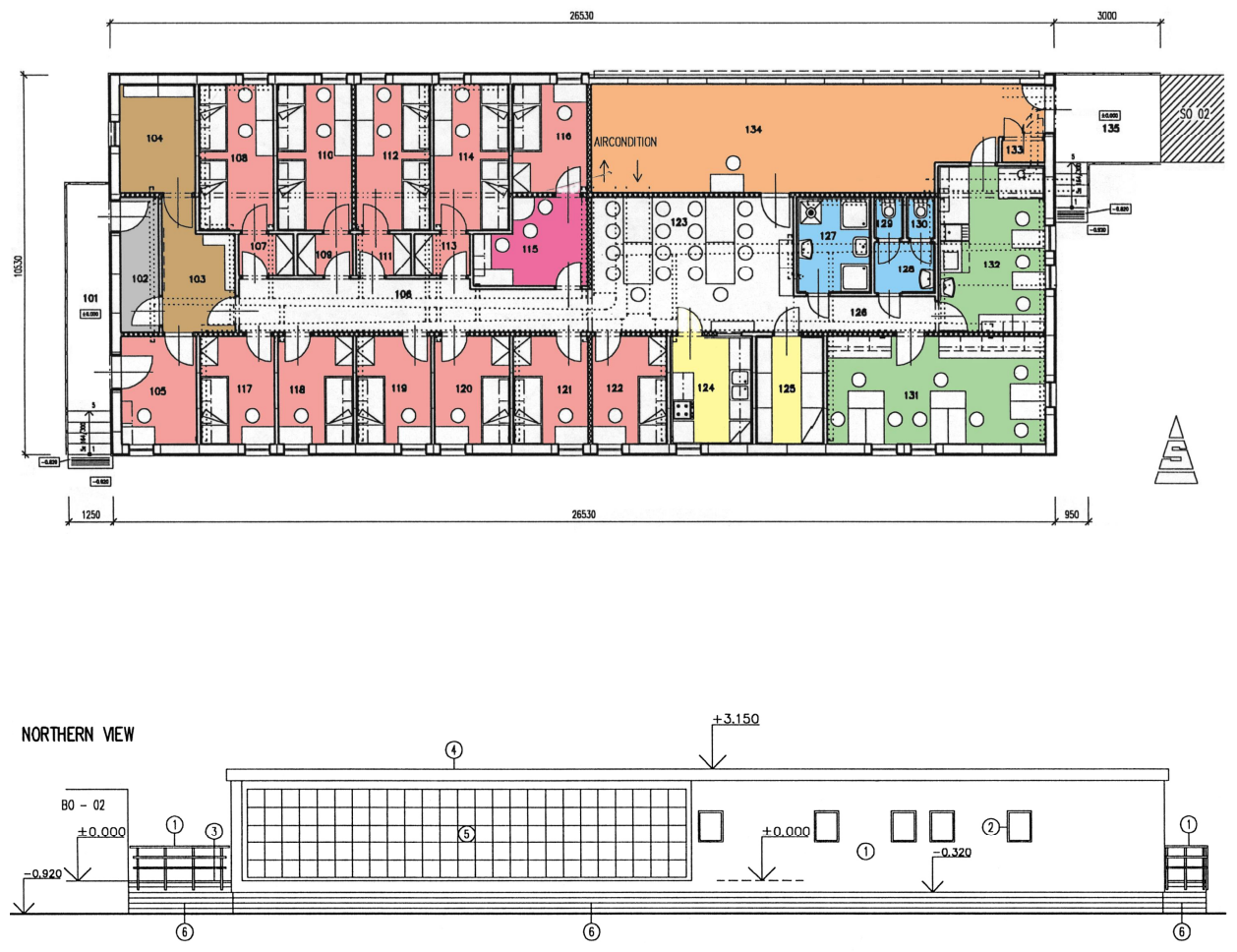

MESTERN MEW

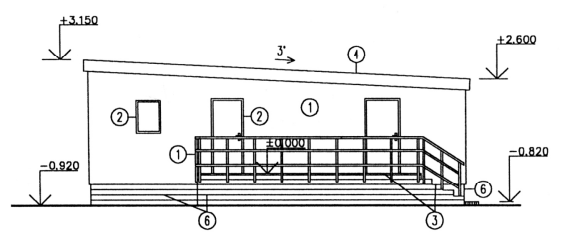

(1) EXTERNAL SKIN AND GUARD-RALL - PANTED UTH PUR PANT - LUMINESCENT RED (2) WOOOEN STRUCTRRES ( WNDOWS, DOORS ) - DISPERSE PANT, WHITE

3. WOODEN STRUCURRES ( HOOPS, STEEP ON RANPS ) - INPREGNATED WTH IMPREGNATING DARK VARNSH (4) STANDARD RUBBER ROOFING EPON MEMBRANE 3,2 MN THICK, BLACK (5) HOT - AR SOLAR-COLECTOR SYSTEM

(6) BASE STRPS INCL. STRPS UNDER RAMPS- WOODEN SLEEPEPS - IMPREGNATED BY MANUFACTURER - BROWN BLACK
SECTION $A-A^{\prime}$

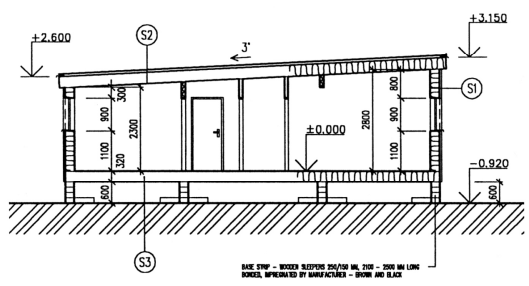

FACULTY OF SCENCE, MASARTK UNIVERSITY BRNO, CZECH REPUBUC CZECH SCIENTIFIC STATION IN THE ANTARCTICA BO 01 CENTRAL UNIT INCL. ACCOMODATON FACUITES NORTHERN MEW, WESTERN MEW, SECTION A-A' SC. 1:125

Fig. 5. Technical scheme of the main station bulding. View from the top shows entrance rooms (indicated in grey and brown), one- and two-bed rooms (pink), radio operator room (deep pink), central corridor and meeting room (white), kitchen and store room (yellow), laboratories (green), bathroom and lavatory (blue), workshop and hot air accumulation room (orange). Side view shows location of hot air collectors. 
Coating of the outer walls is made of a $6 \mathrm{~mm}$ thick waterproof plywood fasted on lath grid. It protects the building against corrosion caused by saltwater aerosols during wind exposures, and mechanical abrasion caused by occasional sand storms. Expected lifetime of the outer walls coating is 15 years.

Overall construction of the building is compact because of its box arrangement of horizontal and vertical elements that are firmly interconnected. The building roof is slightly inclined $(5 \%)$ to the south and covered with a UV resistant sheet made of polyvinyl chloride (PVC). With respect to prevailing wind direction, the orientation of longitudal building axis reduces the dynamic wind impact on the object. Moreover, the east-west orientation of the longitudinal axis with the higher frontage facing north improves the solar energy utilization.

Interior of the station building is divided into several rooms serving for different purposes (see Fig. 5). There are 12 bedrooms (having either 1 or 2 bads, see
Fig. 6), radio room, two laboratories (see Fig. 7), dining and meeting room (Fig. 8), kitchen, bathroom and toilets. There is also a cooled storeroom for food equipped with a freezer for the food that must be kept at subzero temperature. Technical workshop includes three parts: air handling engine room, water heating system and a workshop equipped with basic hand tools.

Additional objects forming the J. G. Mendel station are nine 20-feet cargo containers $(6 \times 2.5 \times 2.6 \mathrm{~m})$ that provide technical background of the station. They are located independently in a close neighbourhood of the main building (see Fig. 9). They serve for several purposes, individual containers are used for food storage, electrotechnical central unit, spare building material, technical tools, diesel engines unit, six-wheel vehicle garage, rubber boats store, fuel and engine store, incinerator and water tanks. Due to their weight, the containers also create sufficient foundations for wind generators because they provide support for the wind generators masts (see Fig. 9).

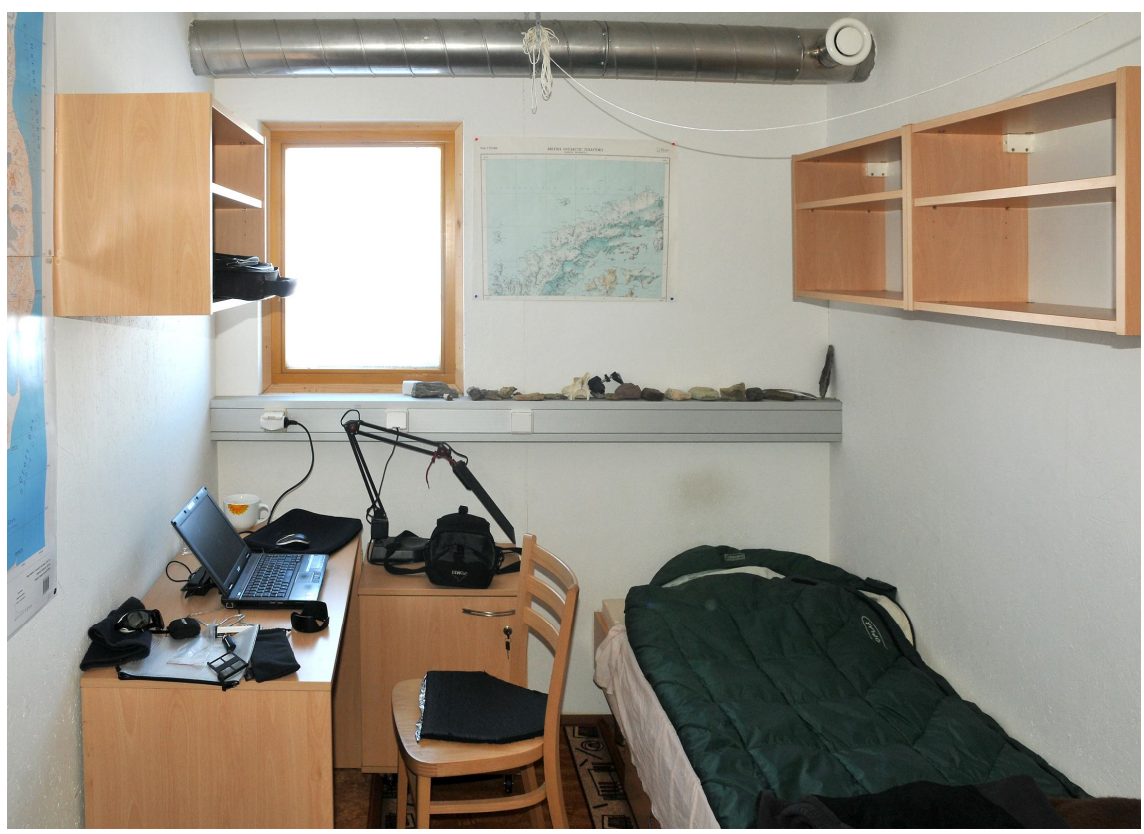

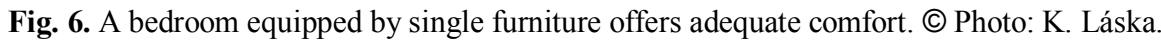




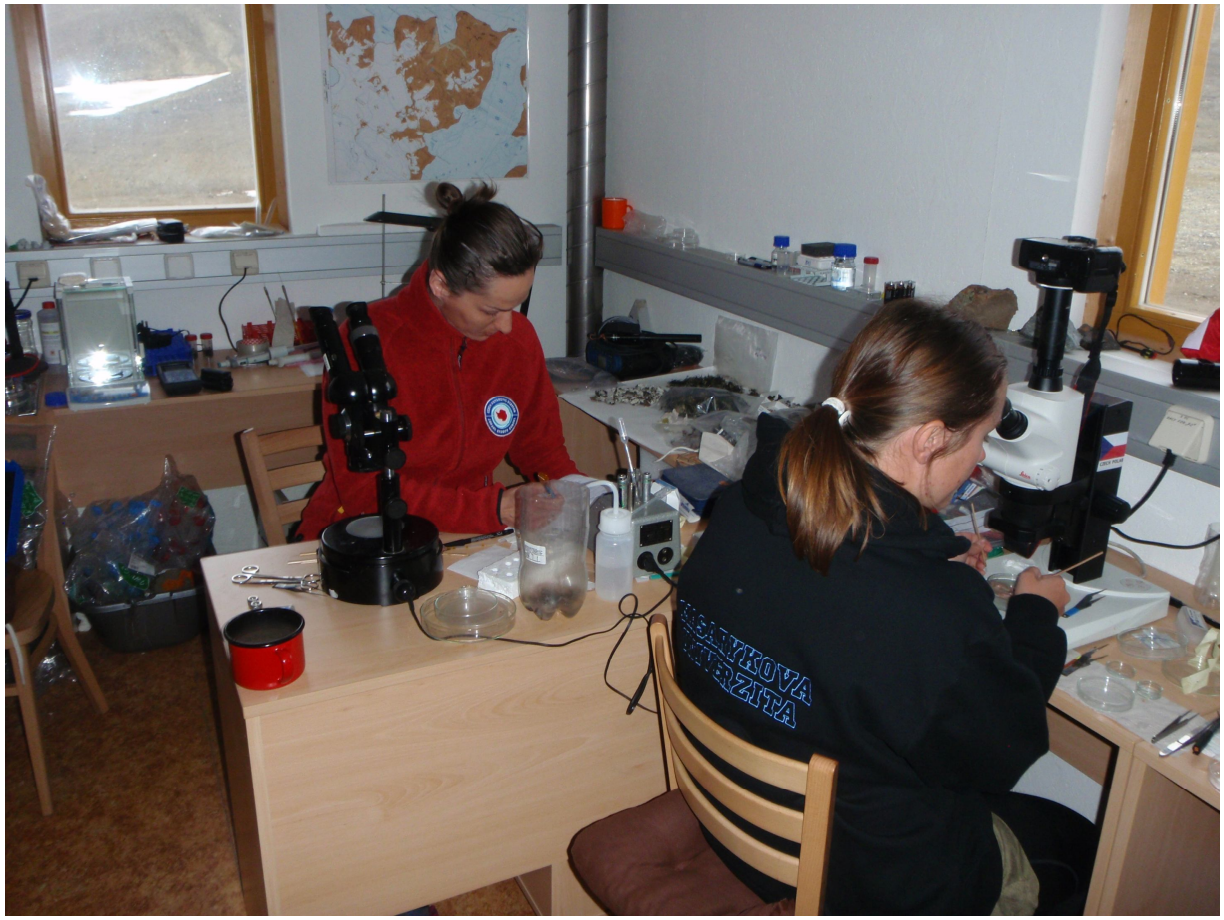

Fig. 7. Two laboratories equipped by fundamental scientific devices form research facilities of main building. (C) Photo: P. Jurajda.

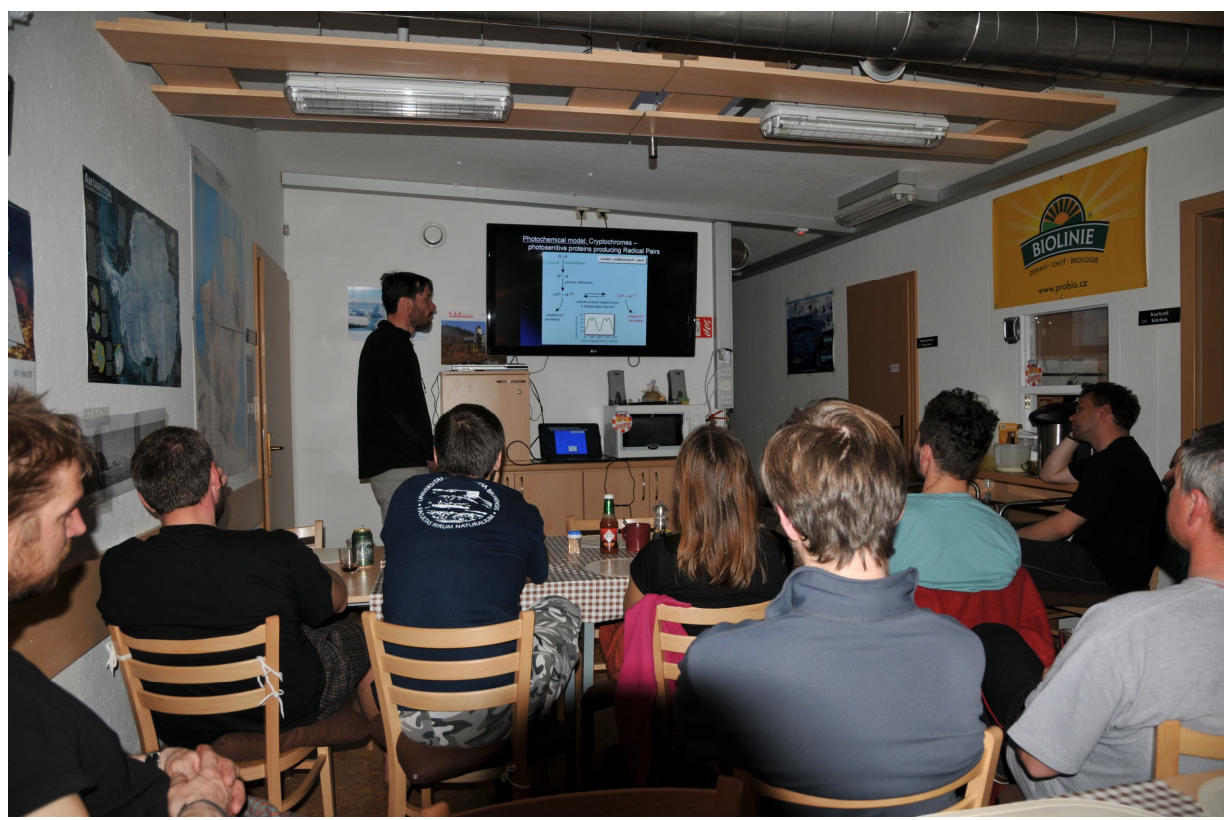

Fig. 8. Dinning and meeting room serves also for evening information about scientific activities. (C) Photo: P. Kapler. 


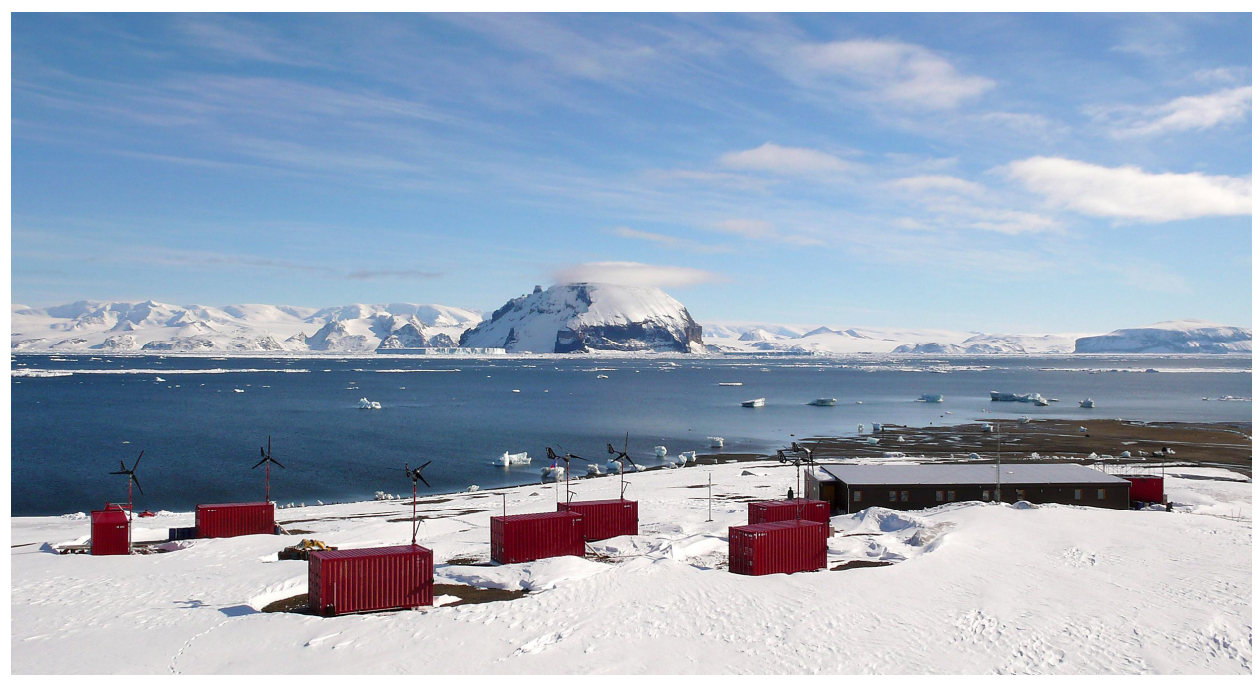

Fig. 9. Significant part of technical systems and storages are placed in standard 20-feet containers. (C) Photo: K. Láska.

\section{Energy sources and their utilization}

With respect to geographical location of the station and height of the Sun above the horizon, solar radiation represents an important source of thermal energy for the building in summer (Láska et al. 2011b). The main station building is heated by hot air. Air conditioning equipment provides the air heating connected to the hot air collectors and heat recovery unit for regeneration of the air exhausting from interior at the end of ventilation system. Such method was selected because of several reasons: (1) very good thermal and technical properties of the building walls, (2) application of renewable energy sources and (3) the requirement to use save heating medium to prevent potential fire. For collection of solar energy, two types of collectors are used. The first one is a hot-air collector area placed on northern side of the building (see Fig. 10). All air collectors (Mistral, EKOSOLARIS, Czech Republic) cover a substantial area $\left(36 \mathrm{~m}^{2}\right)$ of whole north-facing wall of the building. They face north so that absorption of solar energy is optimized.

Air is used as a heat transfer medium from the collectors to central ventilation unit. An individual collector sized 2 x 0.99 x $0.085 \mathrm{~m}$ consists of a stainless steel case inserted into the insulating tub. Inside the case, there are shaped slats of aluminum sheet. The slats form segments equipped with special black cover. From the front side of the collector, the segments are covered by a transparent polycarbonate layer. The heated air, which is output from the collector of sufficient temperature of around $55^{\circ} \mathrm{C}$, is pumped into the flat, 0.6 $m$ wide chamber between outer and inner wall of the building. The heated air from the central ventilation unit streams to the particular rooms (see Figs. 11, 12). Air circulation system consists of a loop passing through all rooms with an inlet and outlet in each room. The air circulation system is equipped with a recuperation of heated air. 


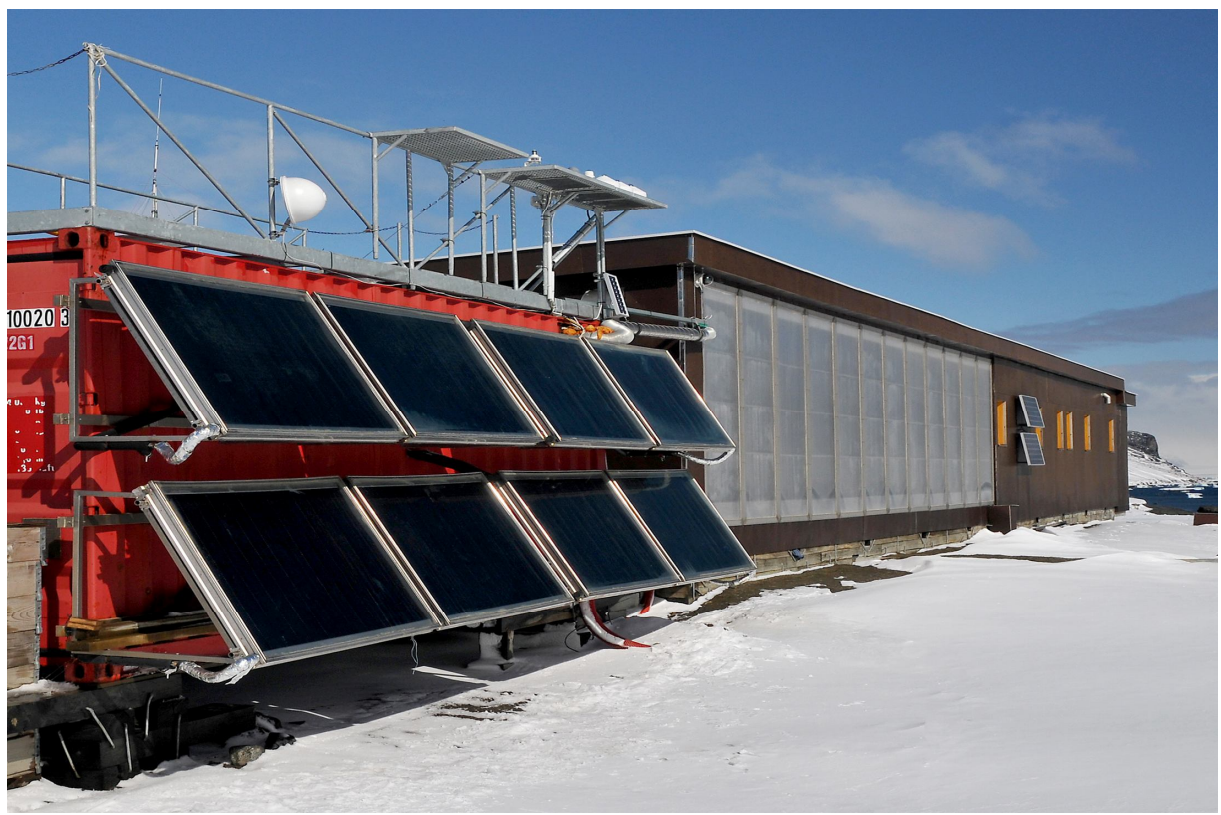

Fig. 10. Hot air collectors (total surface $36 \mathrm{~m}^{2}$ ) on the north side of main building (right side) and thermal pannels (total surface $12 \mathrm{~m}^{2}$ ) installed on the wall of incinerator container (left side). (C) Photo: K. Láska.

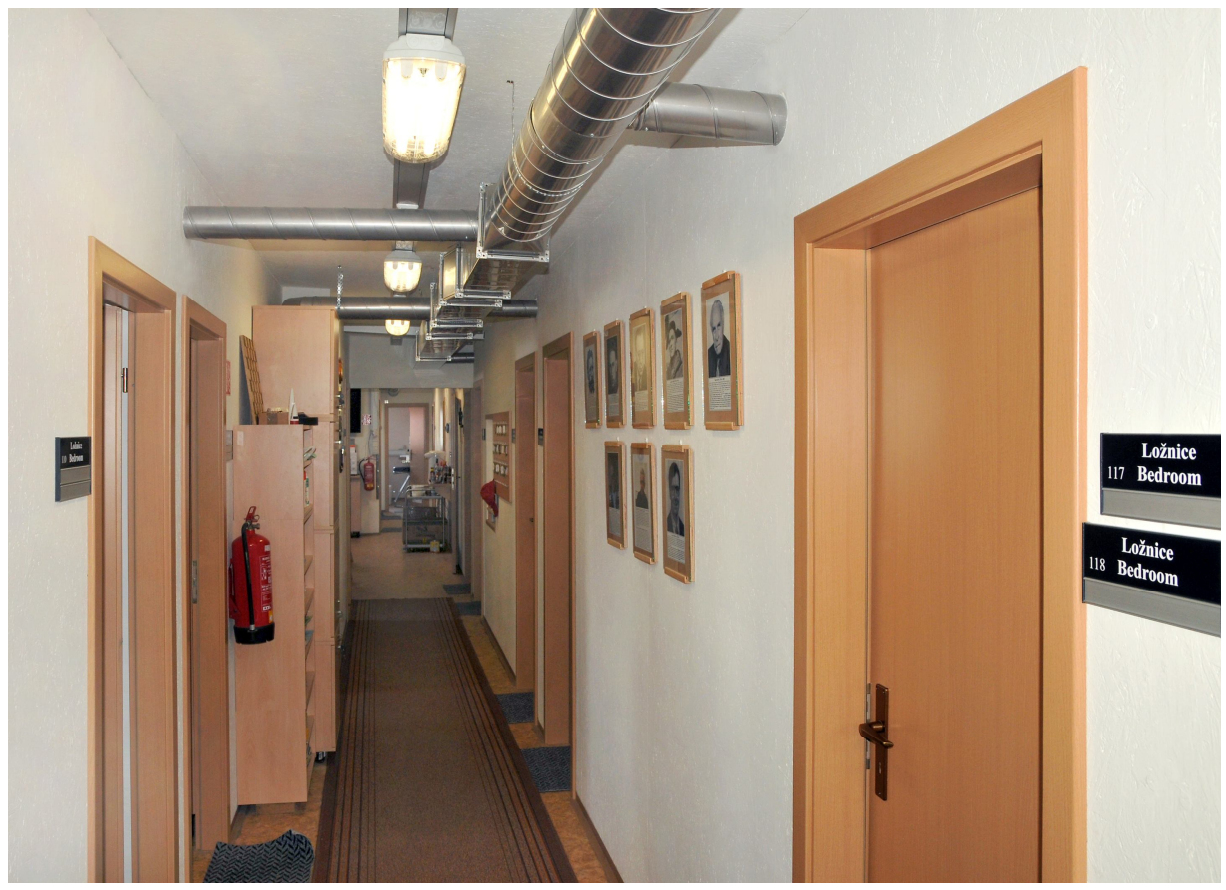

Fig. 11. Central line (along the corridor) and lateral branches of pipes that form a part of heating system delivering hot air to individual rooms. (C Photo: K. Láska. 


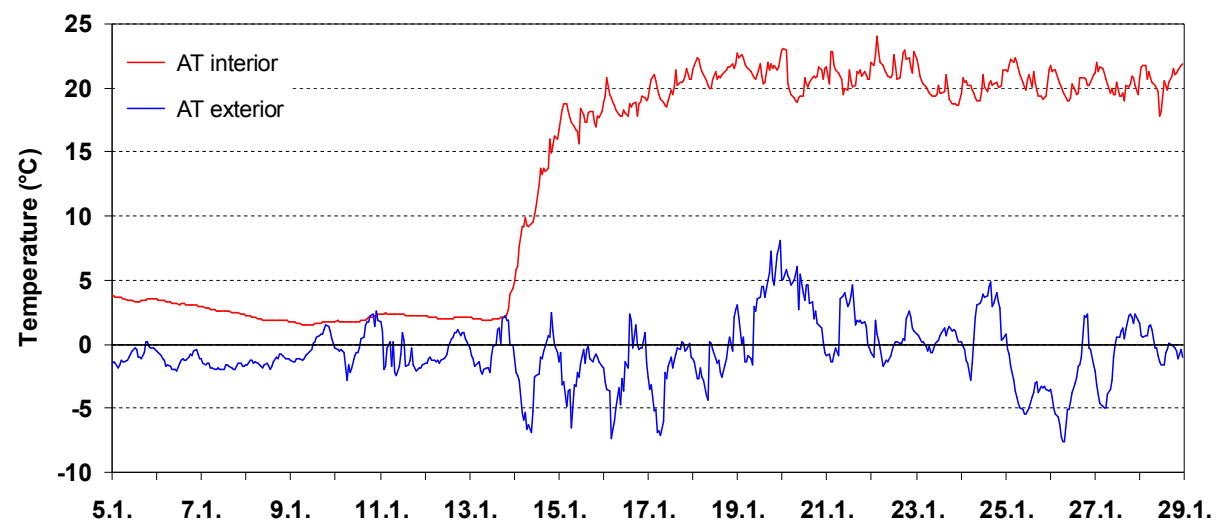

Fig. 12. Air temperature courses recorded outside and inside the J.G. Mendel station (social and meeting room) at the beginning of expedition season 2013. Upon the arrival on Jan. $14^{\text {th }} 2013$, the expedition crew started to operate heating system of the station.

The second type of solar collector is represented by flat-plate thermal panels installed on north-facing wall of the container attached to the station building (see Fig. 10 on the left). The solar thermal panels are mainly used for hot water production. On sunny days, hot water produced by the thermal panels is utilized in the kitchen and bathroom. This system has been in operation since 2007. However, due to generally low number of sunny days during austral summer season, the system was not very effective. Moreover, requirements for sufficient amount of hot water are not high during sunny days because majority of expedition crew is

\section{Wind turbines}

At present, there are two main sources of energy that are utilized for electric power at the J. G. Mendel station. Apart of standard generators (diesel units), 8 wind turbines (type AP1500, MG Plast, Czech Republic, see Fig. 13) with power output of $1.5 \mathrm{~kW}$ each are installed outside the main building of the J. G. Mendel station. The power production produced by wind turbines is stored at two blocks of acidic batteries located in a power supply unit working in outside the station, e.g. in short-term field camps. Therefore, hot water produced on sunny days could be hardly fully utilized in kitchen and bathroom. Requirement for hot water increases rapidly whenever the expedition members are back to the station which happens on stormy and overcast days when no hot water from thermal panels is available. Therefore, the solar thermal panels will be gradually replaced with photovoltaic panels in the next austral summer seasons. Majority of thermal panels removal happened during the last Czech expedition (Jan.-Feb. 2013).

(see Fig. 14, 15A) with a switch gear. After the transformation to AC voltage $(230 \mathrm{~V}, 50 \mathrm{~Hz})$, the electric power is transferred to the station and used by scientific instruments, light, and kitchen facilities. Wind turbine AP1500 is characterized by the following parameters: nominal power of $1500 \mathrm{~W}$, rated wind speed of $10 \mathrm{~m} \cdot \mathrm{s}^{-1}$, cut-in wind speed of $3 \mathrm{~m} . \mathrm{s}^{-1}$, survival wind speed of $50 \mathrm{~m} \cdot \mathrm{s}^{-1}$, rotor diameter of $3.3 \mathrm{~m}$, maximum rotor 
rate at $450 \mathrm{rpm}$. Multipole generator PMG has nominal output voltage $48 \mathrm{~V}$, and together with the rotor weighs $68 \mathrm{~kg}$. Although the wind turbines are designed for harsh environment, the possibility of malfunction cannot be avoided. The main problem is associated with extreme mechanical disturbance of wind turbine parts when there are either high wind velocities and/on frequently changed wind velocities. Recently, preparatory operations take place in order to replace the existing wind turbines by new ones. New wind turbines will exploit advanced technologies and thus reduce probability of mechanical failures.

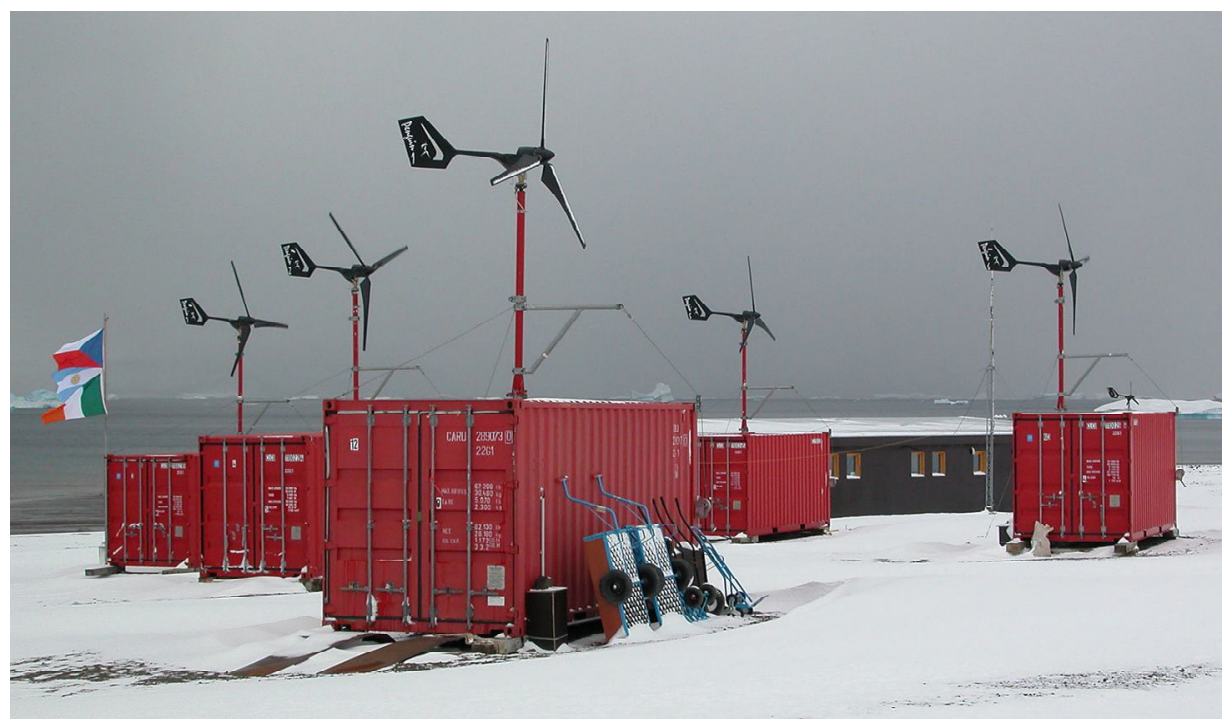

Fig. 13. A group of wind turbines (AP1500) facing SE wind. @ Photo: K. Láska.

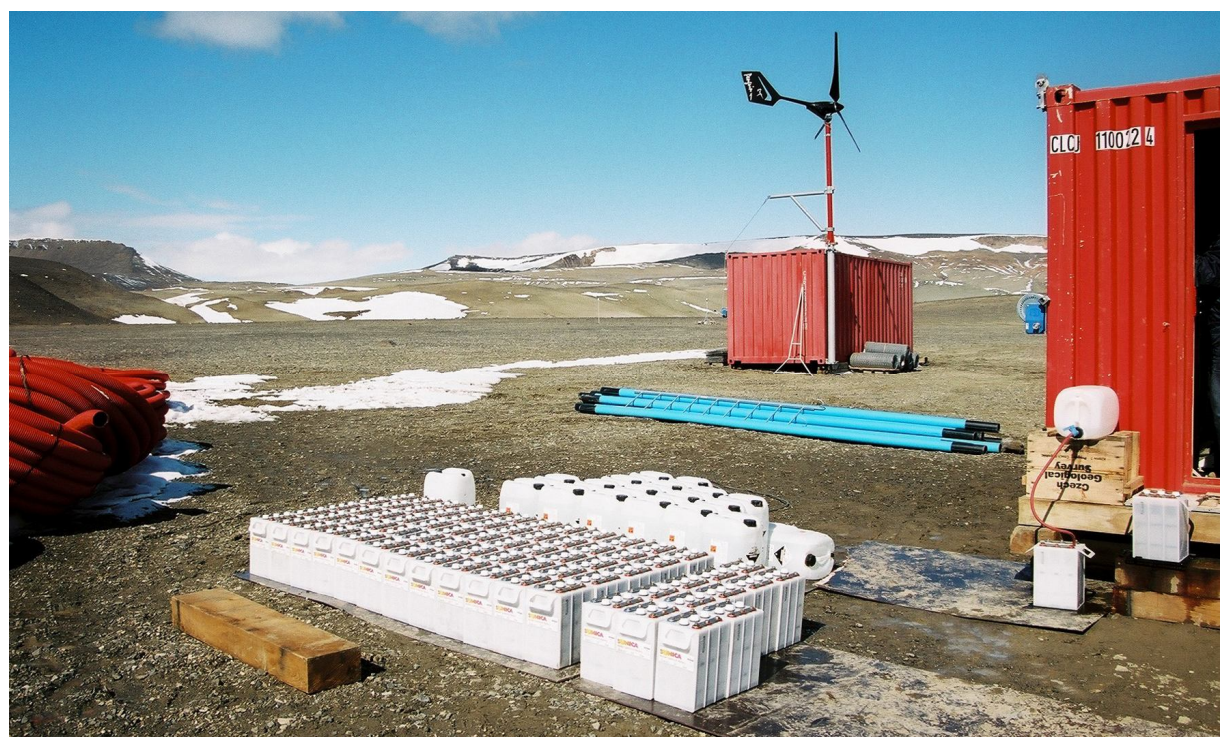

Fig. 14. Part of acidic Ni-Cd batteries before installation into the power supply unit. (C Photo: P. Prošek. 

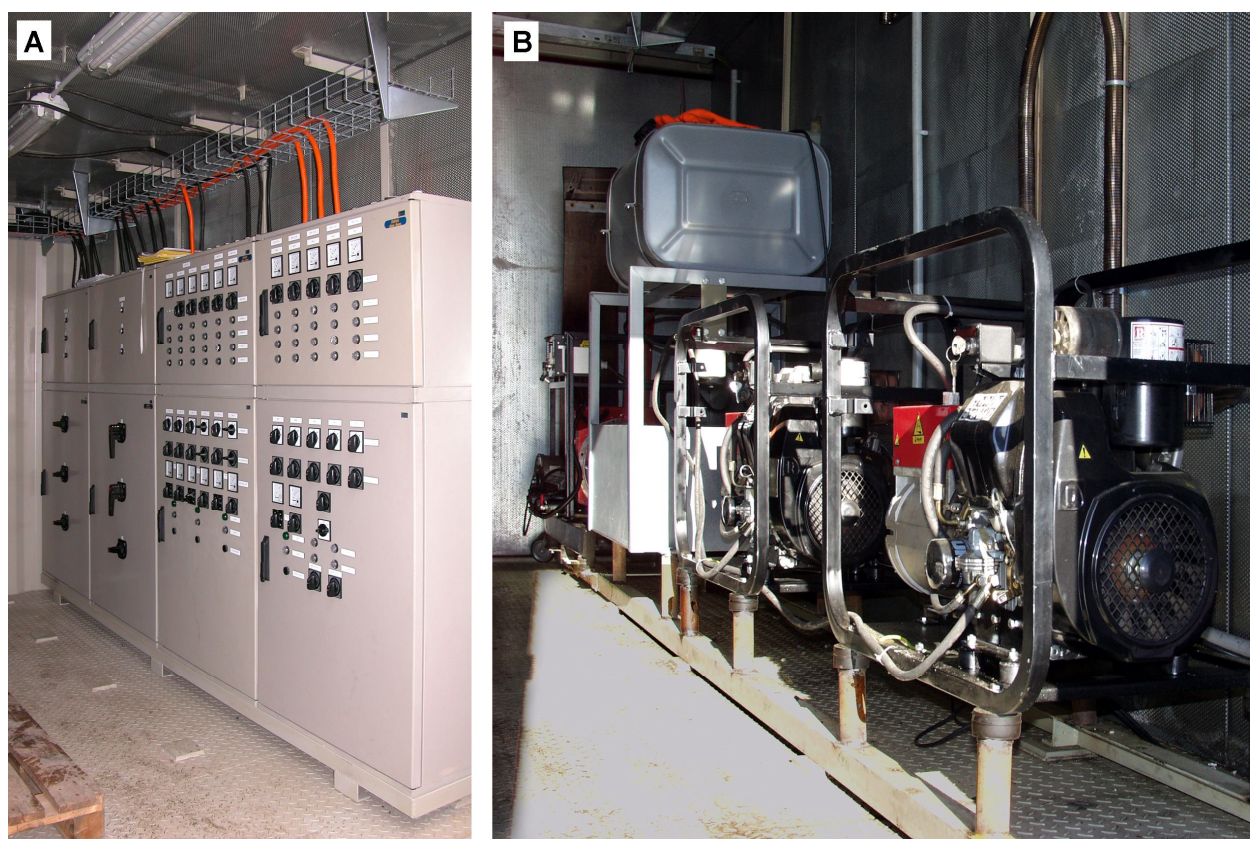

Fig. 15. A - Part of power supply system with the switch gear case. B - Diesel-electric generators after installation in a container. (C) Photo: P. Prošek.

\section{Diesel power generators}

For production of electric power during windless days, there are used dieselelectric generators located in a 20 -feet container. They are fixed to the floor of the container. Two Gesan R12 diesel generators and one R30 diesel generator have sufficiently stabile capacity in $12 \mathrm{~kW}$ / $400 \mathrm{~V}$ and $30 \mathrm{~kW} / 400 \mathrm{~V}$ range (see Fig. 15B). Power generators use low viscosity oil and have independent supported-body system with sound dampers, a transport cart and a pulley equipped with automatic regulation and remote starting option. Internal walls of the container are insulated with a sandwich layer reducing of thermal and acoustic emissions into the ambient environment. Electric power produced by diesel engines is distributed to a power supply unit (another container) accumulated in $\mathrm{Ni}-\mathrm{Cd}$ batteries with a nominal voltage of $48 \mathrm{~V}$ from which the electricity is supplied to the main building of the J. G. Mendel station. The batteries compensate the disproportion between energy supply from the renewable energy sources (wind turbines) and diesel engines and actual energy consumption by the station. If there is a serious failure of the electric power supply, the capacity of fully-charged batteries assures about 10 $\mathrm{kWh}$ for 24 hours (expected average consumption). 


\section{Water management}

For the J. G. Mendel station, a neighbouring stream supported by water from melting snow patches and frozen ground is the main source of technical and drinking water. The stream provides running water throughout majority of austral summer season. It may, however, freeze shortly in late February and the be-

\section{Communication system}

Since 2004 and the first Czech scientific expedition to James Ross Island, the use of satellite communication system is essential for connections of the expedition with the world for safety reasons and other logistic requirements. At the beginning, satellite system Iridium and Motorola mobile phones were used for calls and data services. However, the atmospheric disturbances and low bit rates frequently caused connection drops during the first minutes of data transmission. Initial problems resulted in the finding of new solutions and technologies. Since the establishment of the J. G. Mendel station in 2007, new technologies and communication techniques has been designed in cooperation with the Faculty of Electrical Engineering, Czech Technical University in Prague.

Design of the new communication system for J. G. Mendel station was based on the requirement for data transfer from the station to the Czech Republic either during summer (e.g. data sets, photos, e-mails) or within winter season (only the data from autonomous measuring systems). In 2008, the first prototype of selfservice communication device with low power consumption was manufactured (Neruda et. al 2009). The Equipment marked Bender I was transported to the station and subsequently put into operation in January 2009. The device allowed the ginning of March. Using a flexible hose, water is pumped into a special sedimentation tanks located in a cargo container adjacent to the main building. After sedimentation, water is delivered by permanent, thermally insulated pipes to two 300-litre tanks located in the technical room of the main building.

use of Inmarsat satellite network supported by the BGAN terminal (Broadband Global Area Network), wireless interface 802.11 $\mathrm{b} / \mathrm{g}$, internal power supply, and the main control unit. In the next year, based on previous experience, a new communication device Bender II was created (Kocur et al. 2010). Bender II, among other things, allows to connect external UTP cable with Ethernet, data-logger and two IP cameras scanning continuously the nearest surroundings of the station. Time lapse system of camera was set to 1 hour, while only thumbnails were sent to the Czech Republic once a week. Bender II system was plugged into operation in early 2011. At present, Bender III system was successfully tested at the J. G. Mendel station (see Fig. 16). It contains several modifications and extensions of the previous versions, following the requirements of the different power supply (wind turbine, solar panels), minimal internal power consumption, and number of external connected devices. Future plans consider the establishment of online access to all communications equipment on the station, their control. Such system will allow receiving data from several autonomous micro-meteorological devices located hundred to thousand meters from the station and transfer them to the Czech Republic. 

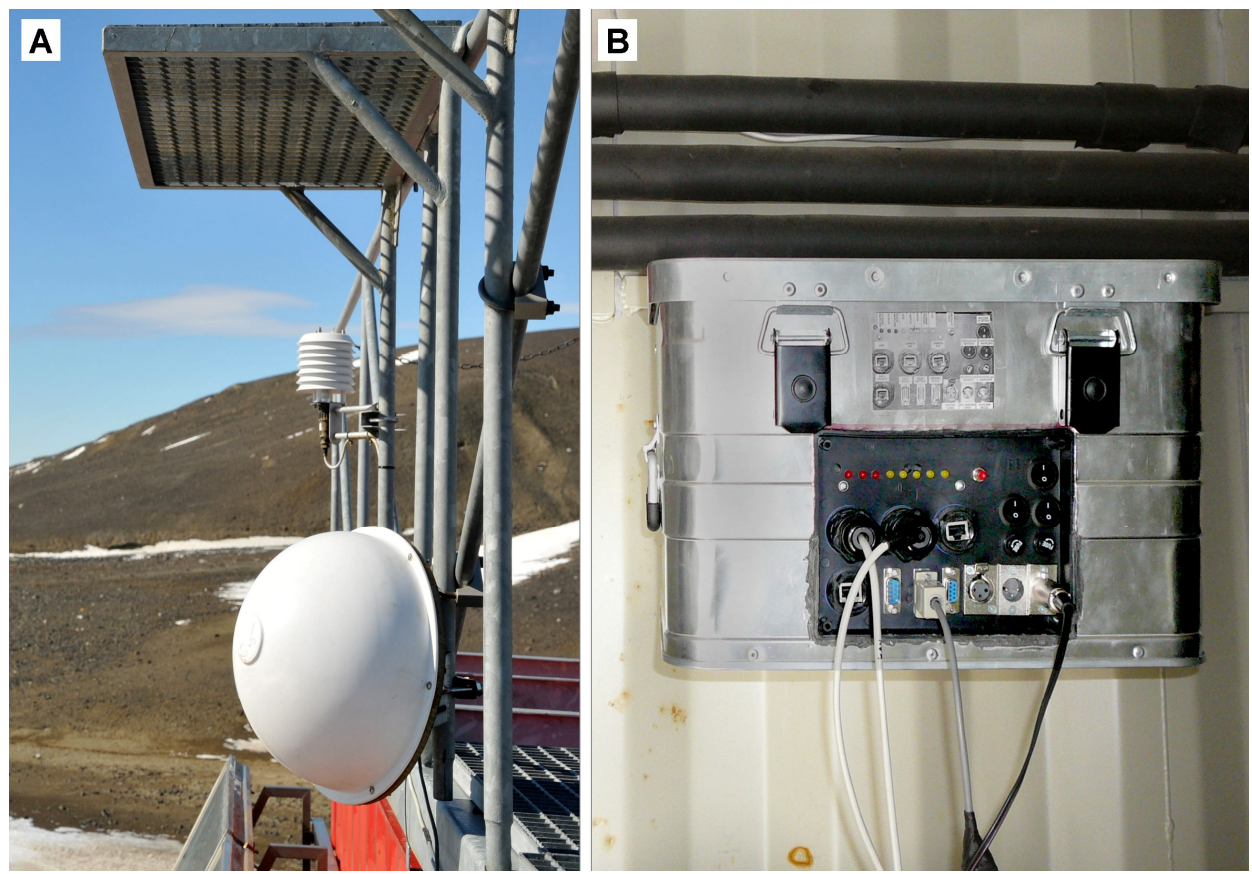

Fig. 16. Communication system Bender III. A - Antenna of the BGAN terminal on the roof of incinerator container. B - Self-service communication device Bender III inside the container. (C) Photo: K. Láska.

\section{Waste management}

Basically, solid and liquid wastes are produced during austral summer (January to March) by operation of the station. The waste comprises the following categories: (1) combustible solid waste, (2) noncombustible solid waste, (3) sewage, and (4) other liquid waste including chemicals. In this paper, only combustible waste management is described into details since the combustion process provides energy for water heating. The J. G. Mendel station is equipped by an OG120SW marine incinerator (TeamTec, Norway, see Fig. 17), which is located in one of the technical containers adjacent to the main building of the station. This incinerator allows to burn sludge oil and solid waste including biological material simultaneously. The maximum capacity for burning sludge oil is $29 \mathrm{l} \mathrm{h}^{-1}$ (IMOspecified sludge oil, 20\% water content). Solid waste is batch loaded into the combustion chamber. Generally, the following materials are burnt: plastic, cardboard, paper, wood, rubber, cloth, oily rags, lubricants, oil filters, diesel engine scavenge scraping paint scraping, food waste, sludge oil, waste lubrication oil etc. During austral summer expedition (Jan.-Feb.), combustible waste is typically burnt 3-4 times after reasonably high volume of waste is heaped up to allow an effective operation time of the incinerator. 


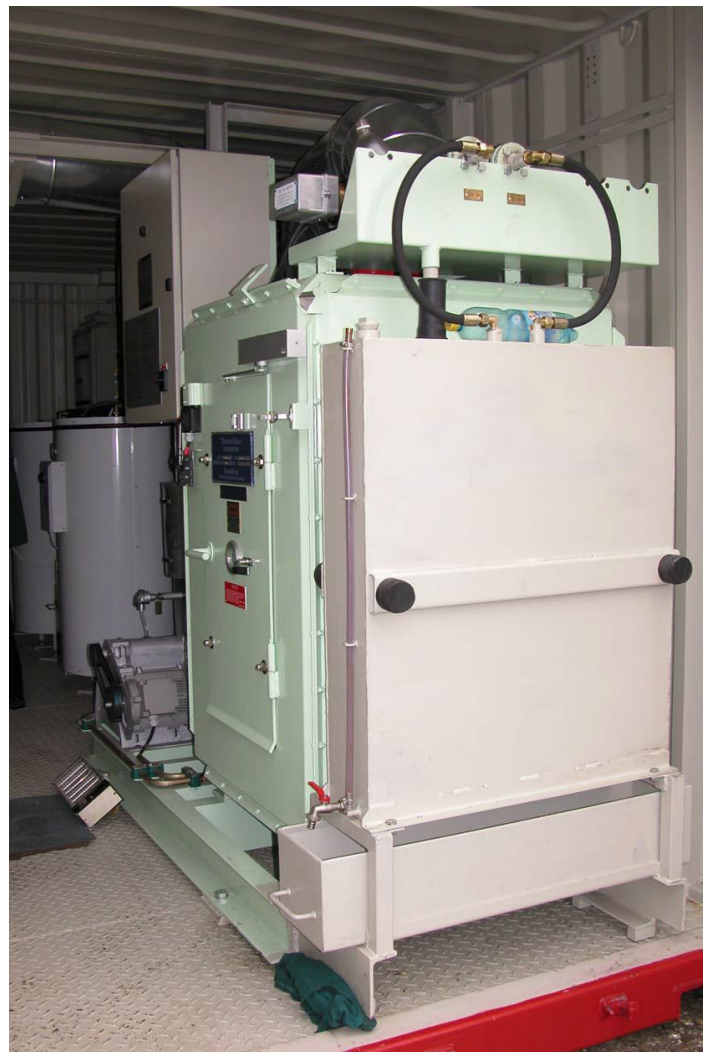

Fig. 17. An OG120SW marine incinerator, right: part of engine room of power supply generators. (C) Photo: P. Prošek.

\section{Concluding Remarks}

In this paper, we brought a detailed description of technical solutions at the Czech Antarctic station J. G. Mendel with the emphasis given to the exploitation of renewable energy sources by the station. We may conclude that, in spite of minor technical limitations, wind power and solar energy represent promising sources of electric power generation for the station. Such combination of renewable energy sources seems to be valid not only for J. G. Mendel station but also majority of Antarctic stations, as demonstrated by e.g. McKenzie et al. (2010). In future, several technical measures will be implemented at the J. G. Mendel station to increase pro- portion of the two sources in overall energy budget of the station. Similar hybrid system consisting of wind turbines, photovoltaic panels and solar thermal collectors is the approach applied recently at the Princess Elizabeth station in a large scale. It is estimated that such approach may cover up to $97 \%$ of energy demands from renewable sources (van Rattinghe 2008). General strategy of energy budget at the J. G. Mendel station will follow two general aims: (1) reduction of fossil fuel consumption and airborne pollution, (2) reduction of demands for logistic supply of fossil fuels. Increased proportion of wind and solar energy exploitation would have, 
however, some limitations in future. Among them, technical and/or mechanical problems associated with wind turbines operation caused by high wind speed and low temperature are of the most importance. It was demonstrated that several types of wind turbines of the same or similar power output should be tested for particular location before final intallation beacause they have different performenace in prevailing wind speed and wind speed distribution that may differ from season to season (Henryson et Svensson 2004). In long-term perspective, lifetime of their rotors and wind turbines foundations are expected to be a challenge (Oswell et al. 2010). Photovoltaic technologies are relatively robust and thus suitable for cold environments. In Antarctica, however cost/ benefit play important role thanks to high transport costs. Therefore, there is a demand for low running costs, long life time and reasonable efficiency of solar energy conversion (Mason 2007). However, an increased application of photovoltaic technologies could be expected in Antarctica in future. Recently, arising technologies offer high efficiency and reliability of photovoltaic panels. They may be used in Antarctic stations as standard in future.

\section{References}

anonymous (2004): Draft Comprehensive Environmental Evaluation for Czech Scientific Station in Antarctica, Construction and Operation. ATCM XXVII, CEP VII, 2004, Cape Town. Working Paper by the Ministry of Environment, Czech Republic, $132 \mathrm{p}$.

anonymous (2007): Construction and operation of the new Belgian Research Station. Dronning Maud Land, Antarctica. Final comprehensive environmental evaluation (CEE). Belgian Federal Public Planning Service Science Policy; March 2007, 123 p.

anonymous (2008): Proposed Construction and operation of the new Chinese Dome A Station Dome A, Antarctica. Final Comprehensive environmental evaluation, $169 \mathrm{p}$.

Broughton, H. G. K. (2010): Antarctic Research Stations: Parallels for Interplanetary Design. Proceedings, $40^{\text {th }}$ International Conference on Environmental Systems, American Institute of Aeronautics and Astronautics. 1-12.

Datta, B. K., Velayutham, G. and Prasad Goud, A. (2002): Fuel cell power source for a cold region. Journal of Power Sources, 106: 370-376.

Guichard, A., Steel, J. (1993): Alternative Energy Systems for Antarctic Stations: Investing for the Future. In: Growth and Environment: Challenging Extreme Frontiers, Proceedings of the Second International Design for Extreme Environments Assembly, 24-27 October 1993, Montreal, Canada, 347-363.

Henryson, M., Svensson, M. (2004): Renewable Power for the Swedish Antarctic Station Wasa. Master Thesis. Royal Institute of Technology, Department of Energy Technology (Stockholm, Sweden), $127 \mathrm{p}$.

Kocur, Z., KozÁK, M., NerudA, M. and BohÁč, L. (2010): Analyzing of Data Flows at Czech Antarctic Station. In TSP $2010-33^{\text {rd }}$ International Conference on Telecommunications and Signal Processing [CD-ROM]. Budapest: Asszisztencia Szervező Kft., p. 219-221.

Leripio, A., Torres, J. P., VianA, M. S. and EChelmeIER, G. R. (2012): Greenhouse gas emissions from the Brazilian Antarctic Station "Comandante Ferraz". American Journal of Industrial Medicine, 55: 1166-71.

LÁska, K., Barták, M., HÁJek, J., ProšEk, P. and Bohuslavová, O. (2011a): Climatic and ecological characteristics of deglaciated area of James Ross Island, Antarctica, with a special respect to vegetation cover. Czech Polar Reports, 1: 49-62.

LÁskA, K., Budík, L., BudíKovÁ, M. and ProšEK, P. (2011b): Method of estimating solar UV radiation in high-latitude locations based on satellite ozone retrieval with an improved algorithm. International Journal of Remote Sensing, 32: 3165-3177. 
MAson, J. S. B. (2007): Photovoltaic Energy at South Pole Station. ANTA504. Graduate Certificate in Antarctic Studies. Christchurch, New Zealand. 58 p.

McKenzie, C., Stephen, K., Xin, Z., Wagner, M. and Wainwright, D. (2010): Windmills in Antarctica. Syndicate Report. University of Cantenbury, New Zealand. Cantenbury, 25 p.

NerudA, M., Kocur, Z., and Burčík, J. (2009): Data Transfer Optimalization via Inmarsat Satellite Network. In TSP - 32 ${ }^{\text {nd }}$ International Conference on Telecommunications and Signal Processing [CD-ROM]. Budapest: Asszisztencia Szervező Kft.

Olivier, J. R., HARMS, T. M. and EsterhuYSE, D. J. (2008): Technical and economic evaluation of the utilization of solar energy at South Africa's SANAE IV base in Antarctica. Renewable Energy, 33: 1073-84.

Oswell, J. M., Mitchell, M., Chalmers, G. and Mackinven, H. (2010): Design, construction and initial performance of wind turbine foundations in Antarctica. Proceedings GEO 2010, Calgary, Alberta, Canada, 997-1003.

Prošek, P., Elster, J., Mixa, P., Suchánek, L., Venera, Z. and Vícha, O. (2006): The Czech Antarctic Station of Johann Gregor Mendel - from project to realization. ATCM working Paper, $54 \mathrm{p}$.

Ramesh, M. P. (2000): Wind energy applications in Indian Antarctic station Maitri, Antarctica. Sixteenth Indian Expendition to Antarctica, Scientific Report, 415-428. Department of Ocean Development, Technical Publication, 14: 1-36.

Steel, J. D. (1993): Alternative Energy Options for Antarctic Stations. Thesis. University of Tasmania, $99 \mathrm{p}$.

Teetz, H. W., Harms, T. M. and von BAckström, T. W. (2003): Assessment of the wind power potential at SANAE IV base, Antarctica: a technical and economic feasbililty study. Renewable Energy, 28: 2037-61.

Tin, T., Sovacool, B. K., Blake, D., Magill, P., El Naggar, S., Lidstrom, S., Ishizawa, K. and BERTE, J. (2009): Energy efficiency and renewable energy under extreme conditions: Case studies from Antarctica. Renewable Energy, 1-9.

van Rattinghe, K. (2008): Princess Elisabeth Research Station at Antarctica Renewable Energy Systems design, simulation and optimization. Master Thesis, Delft University of Technology, the Netherlands, $70 \mathrm{p}$.

\section{Other sources}

Czech Geological Survey. 2009. James Ross Island - northern pat. Topographic map $1: 25$ 000. First edition. Praha, Czech Geological Survey. ISBN 978-80-7075-734-5.

\section{Appendix}

The project of the construction of the J. G. Mendel station was developed by the Investprojekt, Ltd. Zlín, in collaboration with Ecosolaris Kroměříž, the Czech Technical University Prague, and the Technical University Brno. The chief construction contractor was PSG International P.L.C. Zlín. Subcontractors were the following companies: Agama Zlín (water resistant clothes); AREKOP Ltd., (water line and severage system system); AZ KLIMA Ltd., Brno (air-conditioning systems); B. D. I. Ltd. Uherský Brod (furniture); CSM Tisovec (off-road vehicle); Ct Ltd. Komárno, Slovakia (containers); CZECH PAN Ltd. Varnsdorf (wooden elements of station construction); JAANSTAV Ltd. Otrokovice (interior equipment of storage containers); Ekosolaris Kroměřiž (solar equipment); Elma-therm Ltd. Kroměříž (electrosystems); KAISER+ KRAFT Ltd., Praha 
(fuel store, waste store); Marine Equipment Ltd. Nové Město nad Metují (ship equipment); MEVATEC Ltd, Roudnice nad Labem (securing of fuel store); MG PLAST Ltd. Letovice (wind turbines); Saft Ferak Ltd., Raškovice (delivery of accumulators); Švehlák Ltd., Zlín, PFEIFER Metall Holding Ltd., Stochov (workshop facilities); TEAMTEC, Tiederstand, Norway (waste incinerator); VLW Ltd., Malenovice (diesel generators). The shipping was organised by Czechoslovak Ocean Shipping Ltd. 